\title{
Sources of Journal Articles in Select APGA Journals According to Academic Rank of Authors
}

\author{
by Ronald C. Riggs
}

\begin{abstract}
The academic rank of authors of articles appearing in The Personnel and Guidance Journal, The Rehabilitation Counseling Bulletin, Vocational Guidance Quarterly, and Counselor Education and Supervision during 1975, 1976, and 1977 is reported. The greatest percentage of authors (41.19\%) held no academic rank. Relative to their colleagues with academic rank, Assistant Professors were most frequently represented. Students and Instructors were infrequently represented. Variables that may influence the observed frequency of authorship as well as limitations of this study are discussed. It is recommended that counselor educators encourage their students to conduct studies and to report the results as part of their training.
\end{abstract}

A number of studies have reported characteristics of journal article authors, including institutional affiliation (Katz \& Brophy 1975; Baruth \& Miller 1977) and graduate schools attended (Walsh, Feeney \& Resnick 1969). This study reports the academic rank-assistant professor, associate professor, professorof authors of articles appearing in four APGA journals, The Personnel and Guidance Joumal, The Rehabilitation Counseling Bulletin, Vocational Guidance Quarterly, and Counselor Education and Supervision, during 1975, 1976, and 1977 to determine the relative productivity of persons in each rank.

The often heard "publish or perish" dictim might lead one to expect assistant professors to have the highest motivation to publish and professors to have the least such motivation and further expect this to be reflected by their frequency of publishing. Conversely, professors, by achieving that rank, have a history of articles being accepted for publication; if such acceptance has reinforcement value, one would expect them to have article-submitting behavior as a high probability response. However, a number of factors, including the increase in the proportion of one-year appointments at the assistant professor level, the naturally greater prestige of professors who have a history of publishing, a general lack of funding for the support of ongoing research, and other factors, might be confounding variables in this process. Thus, no formal hypotheses are made or tested; the data are simply reported.

Ronald C. Riggs is an assistant professor of guidance and counseling at the University of Michigan, Ann Arbor.

\section{Methodology}

A tabulation was made of the academic rank (or lack thereof) of the authors of each of the 492 articles $^{1}$ in the 1975, 1976 , and 1977 issues of the Personnel and Guidance Journal, the Rehabilitation Counseling Bulletin, the Vocational Guidance Quarterly, Counselor Education and Supervision. ${ }^{2}$ The academic rank used was that given; where it was not possible to make a determination, ${ }^{3}$ the rank was scored "No Rank" as was the case for those authors affiliated with a university in a position without academic rank or those authors not affiliated with a university. In cases of multiple authorship, proportional values were assigned to the academic rank represented. A fifth group, that of students and lecturers-instructors, was also added.

\footnotetext{
1. In the Personnel and Guidance Joumal, articles under the heading Articles were included; those under the headings of In the Field, Poetry, Reflections, and Departments were excluded. In the Rehabilitation Counseling Bulletin, articles in the nonheaded section were included; those under the hearings In Brief and Interchange were excluded. In the Vocational Guidance Quarterly, articles under the heading Articles were included; those under the headings Verse, Salmagundi, Readers Write, Practically Speaking, Serendipity, Editorial, Current Career Literature and Films were excluded. In Counselor Education and Supervision, articles in the nonheaded section were included; those under the headings Editorial, Supervisors Section, Aces Corner, and Poems were excluded. No attempt was made to further restrict the sample by qualitative ratings.

2. This includes for the Personnel and Guidance Joumal Volume 53 Number 5 through Volume 56 Number 4; for the Rehabilitation Counseling Bulletin Volume 18 Number 3 through Volume 21 Number 2; for the Vocational Guidance Quarterly Volume 23 Number 3 through Volume 26 Number 2; and for Counselor Education and Superviston Volume 14 number 3 through Volume 17 Number 2

3. In a small number of cases, statements made regarding authors' positions were worded to imply that it was likely that the authors had an academic rank but no rank was stated explicitly. In such cases, No Rank was scored; this is not seen as having significantly biased results.
}

\section{Results}

The data is summarized in Table 1 , an examination of which shows several trends. The greatest percentage of authors (41.19\% overall) fell into the No Rank category. The three academic ranks, Assistant Professor, Associate Professor, and Professor were approximately equally represented $(19.00 \%, 17.11 \%$, and $16.72 \%$ respectively) overall. Finally, only a small percentage of authors (5.98\% overall) were either instructors, lecturers, or students.

An examination by journal reveals that the highest percentage $(27.93 \%)$ of articles in Counselor Education and Supervision was contributed by Assistant Professors; this is the only journal in which this is the case. In all other journals surveyed, the highest percentage of articles was contributed by persons in the No Rank category $139.78 \%$ in the Personnel and Guidance Joumal, $49.82 \%$ in the Rehabilitation Counseling Bulletin, and $49.05 \%$ in the Vocational Guidance Quarterly). In all cases, the studentinstructor category was least frequently represented.

To examine the relative productiveness of authors with academic rank, those three categories were extracted and reviewed separately. These data are summarized in Table 2. Relative to their colleagues with academic rank, Assistant Professors were most frequently represented overall $(35.97 \%)$ and in three of the four surveyed journals (Rehabilitation Counseling Bulletin, 47.59\%; Counselor Education and Supervision, 41.55\%; and Vocational Guidance Quarterly, $37.26 \%$ ). Only in the Personnel and Guidance Joumal, where Associate 
Table 1

Frequency of Authorship in Personnel and Guidance Journal (P\&G), Rehabilitation Counseling Bulletin (RCB), Counselor Education and Supervision (CES), and Vocational Guidance Quarterly (VGQ) during 1975, 1976, and 1977 and Percentage by Journal According to Academic Rank: Assistant Professor (Asst), Associate Professor (Assoc), Professor (Prof), No Rank (NR), and student/instructor (st/inst).

\begin{tabular}{|c|c|c|c|c|c|c|}
\hline \multirow[b]{2}{*}{ Journal } & \multicolumn{6}{|c|}{ Rank } \\
\hline & Asst & Assoc & Prof & $\mathbf{N R}$ & st/inst & Total* \\
\hline P\&G & $\begin{array}{c}29.92 \\
(15.34 \%)\end{array}$ & $\begin{array}{c}41.33 \\
(21.19 \%)\end{array}$ & $\begin{array}{c}36.33 \\
(18.63 \%)\end{array}$ & $\begin{array}{c}77.58 \\
(\mathbf{3 9 . 7 8 \% )}\end{array}$ & $\begin{array}{c}9.83 \\
(5.04 \%)\end{array}$ & $\begin{array}{l}195 \\
(99.98 \%)\end{array}$ \\
\hline $\mathrm{RCB}$ & $\begin{array}{l}19.75 \\
(20.79 \%)\end{array}$ & $\begin{array}{c}11.83 \\
(12.45 \%)\end{array}$ & $\begin{array}{c}9.92 \\
(10.44 \%)\end{array}$ & $\begin{array}{c}47.33 \\
(49.82 \%)\end{array}$ & $\begin{array}{c}6.17 \\
(6.49 \%)\end{array}$ & $\begin{array}{l}95 \\
(99.99 \%)\end{array}$ \\
\hline CES & $\begin{array}{l}24.58 \\
(27.93 \%)\end{array}$ & $\begin{array}{l}17.25 \\
(19.60 \%)\end{array}$ & $\begin{array}{c}17.33 \\
(19.69 \%)\end{array}$ & $\begin{array}{l}21.83 \\
(24.81 \%)\end{array}$ & $\begin{array}{l}7.00 \\
(7.95 \%)\end{array}$ & $\begin{array}{l}88 \\
(99.98 \%)\end{array}$ \\
\hline VGQ & $\begin{array}{l}19.25 \\
(16.89 \%)\end{array}$ & $\begin{array}{l}13.75 \\
(12.06 \%)\end{array}$ & $\begin{array}{l}18.67 \\
(16.38 \%)\end{array}$ & $\begin{array}{l}55.92 \\
(49.05 \%)\end{array}$ & $\begin{array}{l}6.42 \\
(5.63 \%)\end{array}$ & $\begin{array}{l}114 \\
(100.01 \%)\end{array}$ \\
\hline Total* & $\begin{array}{l}93.50 \\
(19.00 \%)\end{array}$ & $\begin{array}{l}84.16 \\
(17.11 \%)\end{array}$ & $\begin{array}{l}82.25 \\
(16.72 \%)\end{array}$ & $\begin{array}{l}202.66 \\
(41.19 \%)\end{array}$ & $\begin{array}{l}29.42 \\
(5.98 \%)\end{array}$ & $\begin{array}{l}492 \\
(100.00 \%)\end{array}$ \\
\hline
\end{tabular}

* Total may not equal $100 \%$ as a result of rounding error.

Professors were most frequently represented (38.42\%), were Assistant Professors least frequently represented $(27.81 \%)$.

In summary, the group most frequently represented was that of No Rank $(41.19 \%)$ and the group least frequently represented was that of Student-Instructor $(5.98 \%)$. When compared to their rank-holding colleagues Assistant Professors were most frequently represented $(35.97 \%)$

\section{Discussion}

One limitation of the current study is that other, non-APGA journals were not included. Obviously, not all authors in this field submit manuscripts exclusively to APGA journals. Thus, the sample may be biased. Another limitation is that the data base included only manuscripts that were published; there is undoubtedly some discrepancy between articles submitted for publication and those actually accepted.

The relatively high representation of authors with no academic rank may be a function of several interacting variables. It may be that these authors are producing manuscripts of a more practical (as opposed to more "pure" or "basic" research) nature. If so, the editorial policy of any one journal at a given time may favor such manuscripts or not; because revolving editorships tend to be the rule rather than the exception, shifting editorial policies might be expected. Another possible variable influencing the representation of authors with no rank is that when such authors choose to do empirical research they may have more ready access to a subject pool. For example, cannot be said with certainty. However, the nature of the job market and of promotion procedures provide persons at this level with incentive to publish.

A final consideration is the lack of publications by students. Counselor educators might endeavor to generate greater interest in conducting research in their students and to facilitate their efforts in actually conducting research or writing a manuscript. This, it would seem, has the possibility of being a mutually rewarding activity.

The above statements are offered as an initial effort to shed some light on the at times seemingly quixotic question of publication, and to begin to generate a response to Warnath's and Mitchell's (1977) assertion that "who publishes in any particular year is as much a matter of scheduling, luck, faddish topics, and political consideration as it is of pure productivity."

\section{References} attempting to research a topic for publication in the Rehabilitation Counseling Bulletin may have a difficult time locating appropriate subjects. Conversely, such persons researching a topic for publication in Counselor Education and Supervision may have much less difficulty.

When compared with their rankholding colleagues, it would seem that Assistant Professors may be slightly more productive, at least with regard to the surveyed journals. This may indicate that one-year appointments at the Assistant Professor level are not detriments to their conducting research, although this persons with academic appointments
Baruth, L. G., \& Miller, G. M. A study of professional contributions by counselor education faculties. Personnel and Guidance Joumal, $1977,56,44-46$.

Katz, G. M., \& Brophy, A. L. Institutional sources of articles in the Joumal of Counseling Psychology, 1962-1973. Joumal of Counseling Psychology, 1975, 22, 160-163.

Walsh, W. B.; Feeney, D.; \& Resnick, H. Graduate school origins of Journal of Counseling Psychology authors. Joumal of Counseling Psychology, 1969, 16, 375-376.

Warnath, C. F., \& Mitchell, W. J. An Invited Response: limited criteria units $\times$ disputable weights/uncertain staffing abstraction $=$ total misinformation. Personnel and Guidance Joumal, 1977, 56, 47-49.
Table 2

Frequency of Authorship in Personnel and Guidance Journal (P\&G), Rehablitation Counseling Bulletin (RCB), Counselor Education and Supervision (CES), and Vocational Guidance Quarterly (VGQ) during 1975, 1976, and 1977 and Percentage by Journal According to Academic Rank: Assistant Professor (Asst), Associate Professor (Assoc). and Professor (Prof).

\begin{tabular}{llllc}
\hline \multirow{2}{*}{ Journal } & \multicolumn{4}{c}{ Rank } \\
\cline { 2 - 5 } P\&G & Asst & Assoc & Prof & Total* \\
\hline \multirow{2}{*}{ RCB } & 29.92 & 41.33 & 36.33 & 107.58 \\
& $27.81 \%$ & $38.42 \%$ & $33.77 \%$ & $100.00 \%$ \\
CES & 19.75 & 11.83 & 9.92 & 41.50 \\
& $47.59 \%$ & $28.51 \%$ & $23.90 \%$ & $100.00 \%$ \\
vGQ & 24.58 & 17.25 & 17.33 & 59.16 \\
& $41.55 \%$ & $29.16 \%$ & $29.29 \%$ & $100.00 \%$ \\
Total* & 19.25 & 13.75 & 18.67 & 51.67 \\
& $37.26 \%$ & $26.61 \%$ & $36.13 \%$ & $100.00 \%$ \\
& 93.50 & 84.16 & 82.25 & 259.91 \\
& $35.97 \%$ & $32.38 \%$ & $31.65 \%$ & $100.00 \%$
\end{tabular}

* Total may not equal even numbers because of joint authorship. 